\title{
IFRS - Impact on Indian Banking Industry
}

\author{
CA. Mohammad Firoz (Corresponding author) \\ Cambridge University Press \\ New Delhi, India
}

Tel: 919-910-612-165Ｅ-mail: mohammad.firoz@icai.org

Prof. A. Aziz Ansari

Department of Commerce \& Business Studies

Jamia Millia Islamia, New Delhi, India

E-mail: aaansari54@yahoo.com

Kahkashan Akhtar

Department of Commerce \& Business Studies

Jamia Millia Islamia, New Delhi, India

Tel: 919-899-313-271 E-mail: kasan_akhtar2403@yahoo.co.in

\begin{abstract}
The purpose of this paper is to analyze the impact of IFRS on the Indian banking industry after the implementation on and after $01^{\text {st }}$ April. 2011. This paper is based upon the critical analysis of financial statements of the Indian banking industry, such as business per employee, Capital and reserve, Investments and advances, Net NPA Ratios, and the impact thereon of relevant provisions of IFRS. The limitation of this paper is that it covers only the Indian banking industry and excludes all other industries in India. This paper shows the areas in which Indian banking industry is required to focus before and after the implementation of IFRS and their consequences on the financial statements of the Bank.
\end{abstract}

Keywords: IFRS, Banking, Convergence of IFRS, Financial reporting

\section{Introduction}

In a world where most of the country using International Financial Reporting Standards (IFRS), the most appropriate process is to adopt IFRS immediately. IFRS have been recognized as the global financial reporting standards. At present, it has been adopted by more than 113 countries worldwide. In India, The Ministry of Corporate Affairs (MCA) has recently issued and IFRS convergence roadmap that is applicable to all companies excluding banking and insurance companies. According to the roadmap, companies need to reconvert their opening Balance Sheet in accordance with the IFRS in phased manner. The first phase shall commence from $1^{\text {st }}$ April, 2011. However the convergences of International Financial Reporting Standards from the Indian Accounting Standards involved a lot of issues, such as industry implications, reporting implications, and amendment in various statutory laws and so on.

The finalized roadmap for the convergence of Indian Accounting Standards with the International Financial Reporting Standards (IFRS) with respect to banking companies requires all scheduled commercial banks to convert their opening balance sheets as of April 1,2011. RBI has emphasized to banks that they need to gear up to adopt the new standards. Practical experience from other countries has proved that transition to IFRS can take 18-24 months to fully embed and implement.

As part of conversion process an entity should take in to consequence not only the IFRS that is currently applicable but also future changes in them. The convergence of International Financial Reporting Standards shall change the entire picture of the organization structure of the company. It will transform the method of evaluation of company's performance including earnings management information \& control system, reporting practices, valuation policies. The convergence is not the sole responsibility the finance and accounts department. It required a combined effort of all departments of the organization. 


\section{Status of Indian banking Industry}

The adoption of IFRS has significant consequences on advances, Investments, financial instruments, hedge accounting valuation including regulatory compliances, information technology systems, tax calculations and other areas. At present, various bodies regulate accounting of the bank in India. Banks are also liable for the compliances with the Accounting Standards issued by Institute of Chartered Accountants of India (ICAI). In addition, the Reserve Bank of India (RBI) also prescribes certain mandatory accounting principles that have to be followed by bank. For example, Reserve Bank of India has prescribed accounting guidelines for investments and prudential norms for non performing loans. Since RBI's guidelines are prescribed based on prudence as compared to fair presentation objective of IFRS, the guidelines issued by RBI are not in compliances with the IFRS.

In India, there are only seven out of 32 applicable accounting standards compliant with IFRS. There are 12 standards where there are conceptual differences and 10 standards where the regulatory changes are required. The International Financial Reporting Standards has give preference on consolidation of financial statements for reporting purpose. However in India, no such preference has been given in any accounting standards. The earlier issued Indian accounting standards on consolidation of financial statements is not mandatory whereas IFRS makes it mandatory. Its resultant all the banks in India is required to do consolidation of their subsidiaries. The International Financial Reporting Standards gives emphasis over the ratios shows the indication of financials and performances of the organization. It requires the disclosure of those ratios which are key indicators of the business performance and earnings. It also requires the disclosure of the managerial remuneration including any other benefits given to management personnel including bonus, ex - gratia, commission or by whatever name called.

One of important IFRS that shall have major impact over the Indian Banking Sector is IFRS - 9. IFRS - 9 is applicable on all types of financial assets. From a bank's perspective, the key items that are affected include investments in government \& other securities and loan assets. At initial recognition, all financial assets are measured at fair value. The subsequent measurement is based upon the classification of such assets. IFRS - 9 allows little flexibility over the classification of the assets. To be classified at an amortized cost, an instrument must be qualifying in the business model and financial characteristics tests. It is unlikely that an entity can easily change its business model for a particular portfolio to attain a specific classification on initial application of the standard.

The banking industry has started the measurement of credit risk management to avoid any loss in loan assets due to measurement of fair value at the time of implementation of IFRS. It has started the credit risk management internally as well as externally. Although, the bank's internal department measure and assign the risk for all the borrowers before sanctioning and loans and advances. It has also started the practices of getting measurement of risk by external agencies such as CRISIL, CARE and other related for all those entities who enjoys the borrowing facility of 10 Crore or more as group borrower or individual borrower. This practice shall reduce the impairment loss in the advances and shall enhance the net worth as well as income of the banking industry because of no loss in fair valuation.

The statutory regulations prescribed by the Reserve Bank of India, Companies Act, 1956, Income Tax Act, 1961, and other laws of lands, now been discussed for amendments. The Institute of Chartered Accountants of India has already submitted the suitable amendments in the Companies Act, 1956 in the month of May, 2009 before the convergence of IFRS. The Institute of Chartered Accountants of India has suggested amendments in Section 78, Section 80, Section 100, Section 205, Section 208, Section 211, Section 394, Section 391 and Schedule VI of the Companies Act, 1956.

The convergence of IFRS is likely to create significant impact on the banking industry. It shall affect the reporting practices of net worth, capital adequacy, position of advances, valuation of derivatives, financial instruments and so on. It shall also affect the measurement of financial performance of the Indian banking industry.

\section{Impact on Banking Industry}

\subsection{Compliances Burden}

Banks and capital markets institutions have a number of local, national and international regulatory requirements that can trip up even the most sophisticated enterprise. All the policies regarding valuation of loans and advances, capital adequacy, net worth etc are measured as per the rules prescribed by the Reserve Bank of India. Besides the compliances of the rules and regulations prescribed by the Reserve bank of India, the compliances of other laws shall also affect the Indian Banking industry. To illustrate, the International Financial Reporting Standards (IFRS) prescribes that the assets should be depreciated over the useful life of the assets. However the Indian Companies Act, 1956, prescribes the minimum rates of depreciation for the assets under different class of assets. Although the 
companies have the option to charge the higher rate of depreciation but no companies opt as such. At present, all companies are charging prescribed rates of depreciation on the assets only. The compliances burden shall enhance the non-operating costs of the banks. For example, the auditor or the consultants are required to certify the various categories of compliances such as compliances of IFRS, banking regulations, guidelines issued by the Reserve Bank of India, provisions under Income tax etc.

\subsection{Tax Reporting Practices}

The tax considerations associated with a conversion to IFRS, like the other aspects of a conversion, are complex. For banks, tax accounting differences are of great significance. However, the effects of a conversion go beyond these complex tax matters and also include matters such as pre-tax accounting changes on tax methods, global planning strategies, and tax information systems. If a conversion to IFRS is approached properly and well in advance of conversion. it has the potential to strengthen an entity's tax function by providing an opportunity for a detailed review of tax matters and processes.

For differences that impact pre-tax accounting methods banks will need to consider the following questions:

i. Is the new financial reporting standard a permissible tax accounting method under Income Tax Act, 1961 ?

ii. Is the new book method is allowed under Income Tax Act, 1961?

iii. Is it necessary to report changes in methods of accounting after conversion to IFRS?

iv. Will there be modifications in the computation of permanent and temporary differences of Deferred Tax?

v. Is the loss arises due to fair valuation allowed as expenditures under Income Tax Act, 1961?

\subsection{Information Technology}

IFRS is expected to have wide-ranging effects at different levels of the IT systems architecture. The realignment of the banking's information systems will pose a real challenge for their IT department (along with the rest of the organization). Virtually all applications and interfaces in the system architecture can be affected, from the upstream or source of data to the farthest end of the reporting tools. The information technology department of the bank will need to take into account external factors such as local and international regulations, financial consolidation of subsidiaries, stock markets, and external auditors. This business transformation cannot be considered as a one-step project. The updation of the information technology and information systems shall require an investment of bulky amount. The Indian banks have not made any such provisions for meeting out these investments. These investments shall have major impact over liquidity of the banks.

\subsection{Financial Instruments}

The Institute of Chartered Accountants of India has issued AS - 30, AS - 31 and AS - 32 respectively in parallel to International Accounting Standards - 39 (IAS - 39) on Financial Instruments. Financial Instruments: Recognition and Measurement is one of the typical standards for those organizations which use financial instruments in their financial statements especially banking industry. It shall have an impact over the income of the industry. To illustrate the forthcoming key standard IFRS 9, Financial Instruments: Classification and Measurement prescribes two options for the classification of financial assets, i.e. amortized cost or fair value. Amortized cost classification is only permitted, if two conditions are met. First, the asset is held within a business model whose objective is to hold assets in order to collect contractual cash flow. Second, the contractual terms of the financial asset gives rise to cash flows on specified dates that are solely payments of principal and interest on the principal outstanding. When there is more than one infrequent number of sales in a portfolio held at amortized cost, the entire portfolio would have to be accounted for at fair value.

It is important to note that a single entity may have more than one business model for managing its financial instruments, i.e. an entity may hold a portfolio of debt securities that it manages in order to collect contractual cash flows and another portfolio of similar debt securities that it manages in order to trade and realize fair value changes. Banks in India invest in government securities to comply with RBI's statutory liquidity ratio prudential norms. As per current RBI rules, the majority of such investments are accounted for at amortised cost under the "held to maturity' classification. Unless the bank has a clear strategy, sufficient expertise in their portfolio management and a demonstrable history of business models in place. it may well 'taint' an amortised cost portfolio with the result of having to measure the entire portfolio at fair value, causing undesired volatility in their financial statements. 


\subsection{Human Resources}

IFRS involves much more than reorganizing the chart of accounts. It represents a change that cascades well beyond the finance department. Consequently, human resources issues may be a major concern. A conversion project will place increase in demands of the trained and professional personnel, which may come at a time when they are able to handle it. It shall enhance the wages cost as percentage of the total expenses for the bank. To illustrate, State Bank of India \& its associates has 17.03 percent wages of their total expenses in financial year 2009 - 2010 as compared to 15.06 percent and 15.89 percent in $2008-2009$ and $2007-2008$. This cost shall further increase after the appointment of the trained and professional staff for the implementation of the IFRS in the bank.

\subsection{Impairment in Advances}

IFRS recognize the impairment model for the assets of the organization. However, the banking industry, at present recognizes the provisioning and writes off method for the valuation of its advances as per the prudential norms of Reserve bank of India. This is the only guidelines that the Indian banking industry is required to comply. The auditor is required to provide comment on the compliances of these guidelines. The bank is required to examine each and every investment including advances on specific basis and shall require to value them as per the method of present value after adopting the effective rate of interest for discounting. It is a tough work for the banking industry. However the IFRS specify the suitability of method for measurement of present value for group borrower and individual borrower. It specified the collective method and individual method for measurement of impairment of the assets of the organization.

Under IFRS 9, loans and receivable portfolio are accounted on amortised cost basis, provided these loans do not contain any exotic embedded derivatives. Basic embedded derivatives, such as caps and floor or normal prepayment or extension terms, do not taint amortisation accounting. However, amortisation accounting is not possible if a loan has a contractual interest rate that is based on a term that exceeds the instrument's remaining life. Similarly, a loan with a convertible option is not eligible for amortisation accounting and will have to be accounted for on a fair value basis with changes taken to the income statement. Loan portfolio is accounted for on a fair value basis in cases where banks transfer/securities their loan portfolio. Amortisation accounting is also not allowed for certain non-recourse loans, for example, when a loan to a real estate developer states that the principal and interest on the loan are repayable solely from the sale proceeds of a specific real estate. In such cases, the 'contractual cash flow characteristics' is not met and hence, such loans are accounted on a fair value basis.

The advances of the banks for the financial year 2009 - 2010 has been given in the Table - A. At the end of the financial year 2009 - 2010 the total advances was Rs. 3497054 Crore. The bank that has more advances shall be required do more work on the valuation and their appraisal during the conversion of IFRS.

\subsection{Investments}

As per the existing Indian Accounting Standard - 13 (AS - 13) on Accounting for Investments, the Investments of the organization shall be valued on lower of cost or fair value. The calculation of fair value is simple or in other words the value, after deduction of expenditure for sale of such investments, at which it may sold in the open market. However under the IFRS, the measurement of fair value shall be different from the existing method. In India, the banks are required to maintain the Statutory Liquidity Ratio (SLR) and Cash Reserve Ratio (CRR). The banks maintain these ratios by investing in the Governments securities. Hence, these securities cover a major part of the investments of the banks in India. The details of the investments held by the respective groups of banks are given in Table - B. The investments of the Indian banks are approximately 50 percent of the total advances. Hence it shall also require a detailed evaluation during the convergence.

Under RBI norms, investment in equity instruments (other than subsidiaries and joint ventures), are marked to market. Net losses are recognised but net gains are ignored. Under IFRS 9, investments in equity instruments are fair valued. The gains or losses are either recognised in the income statement or in a reserve account. That choice is required to be made at the inception on an instrument by instrument basis, and is irrevocable. With regards to impairment of loans (not covered by IFRS 9), the IASB in a proposed standard is looking at a model that is based on expected losses rather than incurred losses. In other words, the proposed standard requires estimated credit losses to be included in the determination of the effective interest rate for the purposes of amortisation accounting. 


\subsection{Derivatives and Hedge Accounting}

Under the existing Accounting Standards - 30 (AS - 30) on Financial Instruments: Recognition and Measurement. The derivatives are valued at the fair value in the Balance Sheet after making provision for difference in Income Statement for the fair value of such derivatives. The present standards do not require the documents for measurement for fair value for disclosures in the Balance Sheet and Income Statement. However, under the IFRS, all such documents for measurement of fair value must be documented. Besides the documents, hedge effectiveness testing and ineffectiveness testing are also required for measurement of fair value. However if hedge relationship for the qualifying cash flows can be established, fair value measurement need not be applied to such derivatives. It shall have direct impact over the re-measurement of the existing derivatives and hedging instruments.

\subsection{Consolidation of financial statements}

As per the Accounting Standard - 23 (AS - 23) on consolidation of Financial Statement of entities, the consolidation of financial statements are purely based upon the ownership and control over the another organization. As per the existing Accounting Standards, consolidation is not mandatory for all organization. However, as per IFRS, the consolidation is mandatory for all the organization. The measurement and test of ownership shall also be change in the IFRS. It has covered the potential voting rights other than the actual stakeholders. The potential voting rights includes all those whose debts or shares are required to be converted in to equity capital of the company. Indian industries are not practicing any such type of inclusions for examining the applicability of standards on consolidation of financial statements.

The convergence of IFRS shall have impact on all the above things. It is difficult to measure the level of difficulty faced by the Indian banking industry for hedging the risk over investments and advances. At present, many representations have been received by the Institute of Chartered Accountants of India as well by the Ministry of Corporate Affairs from the Indian banking industry for deferment of convergence by some more periods. Further the convergence shall be required for prudential norms of Reserve Bank of India, because it would be difficult for Indian banks to make the two compliances at a single time for different classes of assets.

\section{Impact Analysis and minimization of loss}

The Indian banking sector has started the assessment of the loans and advances of the organization as per the IFRS standards but not full compliances thereof. At present, they measure the quantum of impairment in the loans and advances after applying the proper discounting rates in the calculation of present value. These present value shall be measured after adopting the group borrowing facility basis, in case where the borrowing are enjoyed on class or group basis, and collective basis where the borrower enjoys for shorter period. The example of short period for collective basis is credit cards.

The banking industry has started the measurement of credit risk management. It has started the credit risk management internally as well as externally. Every bank has fixed and assigned certain points for the measurement of risk of the particular loans. These points are based upon the age of the borrower, amount of exposure involves, nature of business or professions, experience in the business, coverage of income to the loans and so on. Although, the bank's internal department measure and assign the risk for all the borrowers before sanctioning and loans and advances. It has also started the practices of getting measurement of risk by external agencies such as CRISIL, CARE and other related for all those entities that enjoy the borrowing facility of 10 Crore or more as group borrower or individual borrower. In every case, the banks examine the default status of the borrower through the CIBIL before sanction of loan. This process is done by the bank internally and the data is kept in confidence. This practice shall reduce the impairment loss in the advances and shall enhance the net worth as well as income of the banking industry.

The banking industry has started the practices for the adequate provisions of the loss for the derivatives and financial instruments. It shall bring the Indian GAAPs at par to IFRS. This practice shall keep the Indian banking industry in good health.

Most of the banks recruited trained and professional staff for the bank. These staff performs the credit risk management, fair valuation of loans and advances forecasting of loss, if any, proper budgeting of income and expenditures. It shall enhance the quality of financial reporting of the banking sector as well as proper valuation of the investments, loans and advances.

Security Exchange Board of India (SEBI) responsible for handling the Indian stock exchange is also in the process of finalization of amendments in the various guidelines issued earlier by them. Any change proposed by the 
Security Exchange Board of India (SEBI) shall require the adoption and implementation by the Indian banking industry.

\section{Conclusion}

The above all discussion shows that the implementation of IFRS shall have the major impact over the advances, financial instruments, investments and but not limited to heavy investment on updation of information technology system. However, still the industry requires a detailed analysis and valuation of existing advances and all other instruments in compliances with the IFRS. The tax authorities has not yet clarified the allowability of the loss arises due to revaluation in such advances and instruments. Reserve Bank of India has also not clarified the compliances of the SLR and maintenance of the other reserve through the investments in the Governments securities and their valuation in contradiction or compliances with IFRS.

All the above things shall have a significant impact over the financial statement of the banking industry. It is not the single process which may be completed in a year but it shall take time. At this time the banking industry has implemented the pension scheme and its resultant has suffered a loss of Rs. 12000 Crore. It has filed a request with Institute of Chartered Accountant of India (ICAI), accounting and auditing governing body, and Reserve Bank of India for making provision in five years instead of putting in the same financial year. Similar treatment may be requested and allowed in future for any loss arises due to fair valuation of the advances, financial instruments and investments.

\section{References}

Baumann. U and Neir. E.. "Disclosure. Volatility and Transparency: An Empirical Investigation into the Value of Bank Disclosure". Federal Reserve Bank of New York Economic Policy Review. September. 2004. 31-45.

BCBS. (2004). Basel II: International Convergence of Capital Measurement and Capital Standards: A Revised Framework. Bank for International Settlements. Basel.

BCBS. (2006). Observed range of practice in key elements of Advanced Measurement Approaches (AMA). [Online] Available: www. bis.org.

Bies. S.S. (2002). Bank Performance and Corporate Governance. BIS Review. No.55. Bank for International Settlement. Basel..

BIS August. (2004). Implementation of the new capital adequacy framework in non- Basel Committee member countries.

Bombay Chartered Accountants Journal. (April 2009). Convergence with IFRS - Impact on fundamental accounting practices and regulatory framework in India.

Buchelt. R., and Unteregger. S. (2004). Cultural risk and risk culture: operational risk after Basel II. Financial Stability Report. [Online] Available: http://www.oenb.at/en/img/fsr_06_cultural_risk_tcm16-9495.pdf.

Chaudhuri. S. (2002). Some issues of Growth and Profitability in Public Sector Banks. Economic and Political Weekly (EPW). June 1. Vol. XXXVII. (22). 2155-2162.

ICAI Publication on Changes required in the Companies Act. (2009). 1956 for convergence with IFRS (Part - I and Part - II) May.

Moosa. I.A. (2007). Misconceptions about operational risk. Journal of Operational Risk. Vol. 1. No. 4. pp. 97-104.

RBI. (2005). Reserve Bank of India Guidance Note on Operational Risk Management dated October 15. [Online] Available: www.rbi.org.in.

RBI. (2007a). Prudential Guidelines on Capital Adequacy and Market Discipline- Implementation of the New Capital Adequacy Framework: Reserve Bank of India circular dated April 27.

Reserve Bank of India. Trends and progress of Banking in India. 2004-2005

Reserve Bank of India. Trends and progress of Banking in India. 2005-2006

Reserve Bank of India. Trends and progress of Banking in India. 2010.

Rising to the Challenge of IFRS. (July 2008). [Online] Available: www.pwc.com/india

Vishwanathan Bharathan. Doddappa Appa Institute of MBA - Indian and International Accounting Standards \& Practices. [Online] Available: www.indianmba.com/faculty_column 
Table A. Advances of the Indian Banks as on 31st March. 2010

(Bank Group-wise)

\begin{tabular}{|c|l|c|}
\hline S. No. & \multicolumn{1}{|c|}{ Name of Banks Group } & Rs. (in Crore) \\
\hline 1. & State Bank of India \& its Associates & 858198.00 \\
\hline 2. & Other Nationalized Banks & 1843102.00 \\
\hline 3. & Private Sector Banks & 632494.00 \\
\hline 4. & Foreign Banks & 163260.00 \\
\hline & Total & 3497054.00 \\
\hline
\end{tabular}

\section{(Source - www.rbi.org.in)}

Table B. Investments of the Indian Banks as on 31st March. 2010

\section{(Bank Group-wise)}

\begin{tabular}{|c|l|c|}
\hline S. No. & \multicolumn{1}{|c|}{ Name of Banks Group } & Rs. (in Crore) \\
\hline 1. & State Bank of India \& its Associates & 377658.00 \\
\hline 2. & Other Nationalized Banks & 828125.00 \\
\hline 3. & Private Sector Banks & 354117.00 \\
\hline 4. & Foreign Banks & 159286.00 \\
\hline & Total & 1719185.00 \\
\hline
\end{tabular}

